\title{
Counteracting Cyber Radical Propaganda on Millennial Teenagers: Perspective Role of the Indonesian Muslim Parents
}

\author{
M. Nur Ghufron ${ }^{1}$, Rini Risnawita Suminta ${ }^{2}$ \\ State Islamic Institute of Kudus ${ }^{1}$, State Islamic Institute of Kediri ${ }^{2}$
}

\begin{abstract}
The present reality shows that the propaganda carried out by radical groups in cyberspace is increasingly rapid. In addition, the reality shows that teenagers are potential internet media users and so many. The purpose of this study is to find out the role of parents to counteract radical religious propaganda in cyberspace in teenagers. This research is qualitative with the subject of Muslim teens at 12 to 15 years old. The technique of collecting data is using deep semi-structured interviews with parents of Muslim teens at 12 to 15 years old in Indonesia ( $N=8$ families) conducted in 2019 . Thematic analysis identifies three main themes: (1) regulation of internet media use to teenagers; (2) Content regulation; and (3) other roles in strengthening the religious understanding of teenagers through the selection of madrasah. The results of this study indicate that the role of parents in counteracting cyber radical propaganda on teenagers is a dynamic process that is built by parents by having attention to the characteristics of teenagers and their context.
\end{abstract}

Keywords: Radical propaganda, cyber, teen, muslim parents.

\section{Introduction}

Propaganda carried out by radical groups in cyberspace is getting higher. They use the rapid development of technology well to spread radicalism, recruitment and mobilization, places of discussion both individuals and groups even to fundraising. Radical groups know very well that cyberspace becomes an ideal battlefield because it is accessible, there are no controls and rules, wide audiences, speed of information, cheap and various other which are more advantages than war in the real world.

Therefore, it is not surprising that radical groups are aggressively making radical sites in the cyberspace are not few. Wiemann in Terror on The Internet [1] revealed astonishing data regarding the development of sites which belong to radicals in the world. In 1998, there were only 12 sites which belonged to radicals. In 2003, the number of radical sites were increased many times to 2,650 . That number has risen again to approximately 9,800 sites in 2014 . It is truly an awful number because it can spread radicalism in several seconds to targeting thousands or even millions of people in various parts of the world.

Meanwhile, most of the current generation of teenagers grow and develop more at home accompanied by various media including the internet. Internet media is widely available in 
most families and is no exception to Muslim families in Indonesia who use new technologies, such as tablets and smartphones. The report entitled The Global State of Digital in 2019 Report stated that in Indonesia the number of internet users was the same as the number of active social media users which were 150 million users. Meanwhile, those who used social media through mobile devices had reached 130 million, up 10 million $(8.3 \%)$ over the past year.

The use of internet media by teenagers raises tension and even ongoing conflicts with children when parents try to balance the educational and social benefits of media use and the negative effects in which some content or certain contacts may have on children's attitudes, behaviors, or safety.

Generally, internet media has both positive and negative influences. Through internet media, children can easily get extraordinary information. However, internet media can also make children uncontrolled to what information they access. This kind of situation can cause children to be able to access porn sites, violence and even radical religious teaching that can influence their thinking processes.

Findings related to positive experiences and outcomes (i.e., opportunities and benefits) can also be divided into the same broad areas: content (e.g., learning new information), contact (e.g., enhancing social competencies), and conduct (e.g., identity expressions). Negative experiences and outcomes (i.e., risks and harm) show that children's technology use can be associated with content risks (e.g., seeing upsetting pictures) [2], contact risks (e.g., receiving unwanted messages from strangers), and conduct risks (e.g., online aggression) [3].

Family is an institution that carries out the duties and responsibilities in achieving educational goals for their children, this is because the implementation of education for children among of them is in the family. In the family, the first time to do interactions which occur in it is between children and parents. Parents are individuals who are known by children to educate and direct children to develop and produce certain personality characteristics and will further influence their attitudes and personality.

According to Youn [4], parental mediation is a form of parental socialization because parents, as the primary socialization agents, influence their children's behaviors and attitudes to become more competent technology users.

In addition, parents in the family are the first fortress which will guard children who actually are the next generation of the radicalism influence. Before entering into radical propaganda, parents must take a main role in protecting their children. Therefore, this study to understand how the role of parents in counteracting cyber radical propaganda on teenagers. 


\section{Method}

\subsection{Participant}

Participants in this study consist of 8 families (Mother $\mathrm{N}=4, \mathrm{~N}$ Father $=4, \mathrm{~N}$ Children $=$ 14) who have at least one 12-to-15-year-old child who uses a tablet, Personal Computer (PC), or smartphone at least once a week. The parents are around 35 to 50 years. Eight complete families consist of father and mother. Education levels are from high school to college. Job of four families are lecturers, two families work as civil servants, and two families work as merchant.

\subsection{Procedure}

Data collection in this study uses deep interviews which are separate between parents and children conducted from April 2019 to June 2019. Interviews take place some at participants' home and some at work. Semi-structured interviews with parents, muslim, and at the time before the initial interview had a view on the importance of mutual support and respect among human beings, the importance of being kind and just among people, and helping in building a harmonious, harmonious and peaceful society. The interview process took place are between 20 and 45 minutes (average 30 minutes). Parents are interviewed about: (1) how parents regulate the use of internet media on teenagers; (2) how parents regulate the content of internet media access on teenagers; and (3) how parents can strengthen the religious understanding of teenagers in other ways.

\subsection{Analysis}

All interviews are transcribed verbatim. For the purpose of this study, only interviews with parents are analyzed. Analysis of research is done thematically through analytical methods [5]. There are six steps thematic analysis method used in this study, among of them: (1) familiarizing themselves with the data through several transcript readings in the file (2) making the initial code to highlight the topic in the data (3) grouping the code into categories and finding themes which are repeatedly (4) reviewing the shown themes (5) defining and naming themes (6) making reports.

\section{Results}

The results of this study indicate that parents of teenagers at 12-15 years old have a way of counteracting radical propaganda in religion in cyberspace through three themes, among of them: (1) regulation of internet media use on teenagers; (2) regulation of accessing content; and (3) other roles in strengthening the religious understanding of teenagers.

A. Regulation of internet media use on teenagers

The family in this study reports that teenagers' internet media is done by using tablets, Personal Computers (PCs), or smart phones. Each of these media has its own weaknesses and strengths when they are used for internet media in teenagers. 
"We use internet media through Personal Computers (PCs), or smart phones, however, the use of both is based on needs."

Some families are more comfortable using the internet with smart phones because it not only functionate as a communication tool, social media is also one of the ways for internet media.

"I buy a smartphone for my child for communication needs with him and also can be used for other needs such as Whats app, Facebook and internet" (Mother, B4).

The results of this study indicate that what is done by parents to manage and control the use of internet media on teenagers has challenges such as because they have cellphones that can be used for internet media. When they have their own smartphone, they also have the opportunity to use it without parental supervision. As a result, these events usually lead to a more liberal strategy, where children are not really controlled, or there is no specific strategy. Parents let their children use their own technology, sometimes without supervision. As shown by a mother (B3):

"When my child played with his friend and brought his cellphone, at that time I could only pray that my child would be fine and did not use his cellphone for negative things, because I could no longer keep my eyes on him".

Parents actually find it difficult to anticipate the various possibilities caused by teenagers to have a cellphone but parents still choose the technology because it can not only be used as a communication tool but also be used as internet media. As a mother (B2) said:

"Because today's mobile phones are quite complete, including internet access, it is also quite important for children, especially for family communication, so we are also quite busy to manage what is done on the cellphone".

However, parents still have a strategy to manage internet media use on teenagers. Some families have strict rules for the use of it and some usually set rules situationally. In families which have strict rules relates to the time which are used for internet media and control the use of it. Some parents make special rules for the use of internet media which is considered something special. For example, in some families, the use of technology for the internet is a form of gift or punishment:

"I use cellphones for the internet as a way to motivate children to do something. For example, when a child wants to play a cellphone, she has to do homework and school assignments first. So when he comes home from school, the first thing to do is to do homework and housework. When they are done, there is time left and there is no problem using internet media, there is a kind of gift"(Father, A2).

Meanwhile for families who do not set the rules because they think that through internet media actually get a lot of information. As argued:

Father: "I never really had the intention to set a rule, because I think through internet media, children can get the information that they need".

Time and place regulation is an important part of the process of regulate internet media usage. Parents report that they distinguish between free time and study time. Strategies can be different on weekends, during holidays, day off, and during school days. As revealed by a father (A3):

"During holidays, there is more freedom but during active school days ... when an older girl comes home from school, first she has to do homework and then she can use internet media."

Different days also make a difference in the strategy process. Some families make habits related to day and night. 
Mother (B2): "I only allow the use of the internet for my child after all housework and homework is finished. For weekdays after seven o'clock in the evening approximately half an hour. While for the holiday rules are loose".

There are also changes to extraordinary events, such as traveling, visits to certain locations and waiting conditions. As a mother said (B2):

"internet usage via cellphone, while traveling or when there is a long waiting period, I allow it."

The results of this study can be concluded that the internet media in the family in this study by using computers, tablets and smart phones. While the use of cellphones for internet media, some families are still regulated and controlled by parents and some families give freedom in certain situations.

B. Regulation of accessing internet media's content on teenagers

The results of this study identify how parents regulate the content of access to teenagers through: accessing limited content as needed and accessing together with parents.

Regulated limited access is a way of parents which is conducted to minimize the access to inappropriate content such as pornography or radical religious teaching.

Mother (B1): "Before a child accesses the internet, I usually give the content limitation which is accessible or not, including religion, except only for assignments at school"

The shared use is also taken when parents have plenty of time to accompany children when accessing the internet. As explained by a father (A1):

"She is a girl, 13 years old, actually she can independently download various information on the internet but I still accompany her so she can choose information that is appropriate for her development including avoiding inappropriate religious knowledge".

Based on the explanation above, it can be affirmed that the families in this study who have rules which one can be accessed and not. Some families set it with limited content filters according to what is needed and others by assisting their child in using internet media and when accessing the internet.

C. Strengthening religion understanding on teenagers

Regarding to friendly religious learning, it is a national challenge faced by Indonesia, because there is still a wrong and narrow religious understanding. This wrong and narrow understanding of religion can lead to radicalism.

The family in this study stated that good religion understanding on teenagers can be obtained through the selection of appropriate madrasah. This is as revealed by father (A4):

"My child is studying religion in Madrasah which I have chosen and InsyaAlloh that Madrasah teaches goodness".

The religious understanding of teenagers in this study is also mentioned that it is only obtained during school because the conditions and situations of children and parents were not possible. As stated by father (A2) below:

"till now I can only rely on my child's religious studies from school because after he came home from school he said he was tired. Even though I have a career so he can get more religious lessons from tutors or attend diniyah schools. Besides that, I myself have no time to teach him". 
Table 1 shows the findings of the results of this study indicate that parents of teenagers at 12-15 years old have a way of counteracting radical propaganda in religion in cyberspace.

Table 1. The role of parents to counteract radical religious propaganda in cyberspace in teenagers

\begin{tabular}{ll}
\hline Main Theme & Super-ordinate Theme \\
\hline $\begin{array}{l}\text { regulation of internet media use on } \\
\text { teenagers }\end{array}$ & $\begin{array}{l}\text { Liberal strategy/ sometimes without } \\
\text { supervision }\end{array}$ \\
& $\begin{array}{l}\text { Parents still have a strategy to regulate } \\
\text { internet media use on teenagers }\end{array}$ \\
$\begin{array}{l}\text { Regulation of accessing internet media's } \\
\text { content on teenagers }\end{array}$ & $\begin{array}{l}\text { Limited content filters according to what } \\
\text { is needed }\end{array}$ \\
$\begin{array}{l}\text { Assisting their child in using internet } \\
\text { media and when accessing the internet }\end{array}$ \\
teenagers
\end{tabular}

The religious understanding of teenagers in this study in addition to religious studies at Madrasahs can also be through the participation of children in activities at the mosque. As stated by the following father (A1):

"My child besides learning religion taught by teachers in Madrasah, he also participates in several activities at the mosque. The selection of appropriate madrasah and participating in activities in the mosque is the main step to monitor the religious material he will get".

Based on the explanation above, it can be affirmed that the role of the family in strengthening the religious understanding which is friendly to teens is through studying religion in appropriate schools or Madrasah and with people who are competent and authoritative, for example teachers, scholars or ustadz who are known to understand religion well and tolerant selection of suitable schools or madrasah and participating in activities in the mosque is the main key to the religious learning of teens.

\section{Discussion}

The results of this study reveal that parents of the 12-to-15-year-old teens have a way of counteracting radical propaganda in religion in cyberspace through three stages, they are: (1) Regulation of internet media use on teenagers; (2) Regulation of accessing content; and (3) other roles in strengthening the religious understanding of teenagers.

The results of this study indicate that the initial role of the family in counteracting radical propaganda in religion in cyberspace is the regulation of teenagers' internet media. In this 
study family reported that the use of internet media for teenagers was done by using tablets, Personal Computers (PCs), or smart phones. Each of these media has its own weaknesses and strengths when it is used for internet media on teenagers. If internet media uses computers, parental control to teenagers can be maintained but this media is less practical for other activities.

On the other hand, if teenagers use cellphones for internet media, parental regulation will get obstacles. When they have their own smartphone, they also have the opportunity to use it to access any internet without parental supervision. As a result, these events usually lead to the more liberal strategy, where they are not really controlled, or there is no specific strategy. Parents let their children use their own media, sometimes without supervision. However, internet media through cellphones have a function as a means of communication, social media, other activities, practical and can be carried everywhere.

However, parents still have a way of regulating the use of internet media on teenagers. Some families have strict rules for the use of internet media and some families usually set rules situationally. Families have strict rules related to the time used for internet media and control the use of internet media. Some parents make special rules for the use of internet media which are considered something special and some provide freedom in certain situations.

Time and place are described by parents as a very important factor in strengthening the role of parents. This result gets along the research of Zaman, Nouwen, Vanattenhoven, de Ferrerre, \& Van Looy [6], which also shows the importance of considering contextual factors, such as when, where, and under external conditions where children are allowed to use the media. Several studies have shown that parents use rules to mediate the use of their children [7]. The results of this study also show that there are not strict regulations in some families, and if there is a regulation, it is set more situational in relation to the context, such as where and when children use technology and also about the needs of parents. This conditions indicate that the parents' role is changing according to the family situation and technological developments which exist.

The next role of family in counteracting radical propaganda in religion in cyberspace is by the regulation of accessing internet media content for teenagers. The results of this study found two ways to set the access content on teenagers by accessing the limited content as needed and accessing together with parents.

The regulation of limited access is one of parents' way to minimize the access of inappropriate content such as pornography or radical religious understanding. Meanwhile the shared use is used when parents have plenty of time to accompany children when accessing the internet. The results of this study broaden the knowledge by revealing the role of Muslim parents in counteracting the radical religious teaching, having challenges according to nowadays technological developments. Thus, the results of this study confirm to counteract the radical teaching on teenagers by controlling or managing the content seen by their teenagers.

According to Mesch [8], research on the role of parents is based on the premise that technology can influence children's attitudes and behavior. The effect of this technology can be influenced by the activities of parents to a certain limitation. However, this study shows 
that parents are also influenced by their child's behavior, which then affects their role. The role of parents is a process of interaction between children and parents who together build the role of parents.

This study shows the role of parents in choosing schools or madrasah aimed to strengthen the religious understanding which is friendly to their teenagers, considering that friendly religious learning is a national challenge faced by Indonesia, because there is still a wrong and narrow religious understanding.

The results of this study also show that friendly religious understanding for teengers is built through religious learning in schools or Madrasah which are appropriate and with competent and authoritative people, for example teachers, scholars or ustadz who have been known to understand religion well and tolerantly. Therefore, the selection of suitable schools or madrasah and participating in activities in the mosque is the main key to the religious learning of teenagers.

\section{Limitation and Future Research}

This research is carried out in only eight families in Kudus, Sleman, Ponorogo and Kediri in Indonesia and to generalize the results are very limited. This study tries to make various samples by using families with different backgrounds. The characteristic of the sample makes it possible to carry out in-depth exploration of families where teenagers have internet access. But unfortunately, this study has not been able to explore more details about how it works in the family when the access is done.

It could be that families with the growing up children like that use different roles because some parents say that they will be a different role in the future when children really want to be independent. It is also possible that the role of parents in the use of internet technology on teenagers varies according to the problem of the character they want to strengthen. This study recommends quantitative and comparative research in the future to validate those hypothesis. This study is only carried out on the parents' perspective, which is a limitation in this study. Future research can be strengthened by the source of teenagers who will certainly get different and deeper results. Another subject is needed to balance the approach of both parties, or at least to know each other's roles from parents or teenagers.

\section{Implication}

The results of this study indicate that the role of parents is a dynamic process which is built together by parents and children in the context of the actual situation. Deep and inclusive religious education is one of the main foundations of teenagers now in fortifying or counteracting radical propaganda in religion.

It is also important to recognize that there is usually no one parent strategy, but it varies according to different situations. "Optimal role" can vary in different places (such as at home, on vacation or while traveling) and at different times (during weekdays, during weekends, or during holidays). Parents should think hard about mediating situations where they have little control over the use of their children's technology, such as when their teenagers go out with their friends. 


\section{References}

[1] G. Weimann, "Terror On The Internet: The New Arena, The New Challenges (2006); Maura Conway, Terrorism and the Internet: New Media-New Threat?, 59 Parliamentary Aff. 2006, 283, 283-92.

[2] M. Smahelova, D. Juhová, I. Cermak, D. Smahel. "Mediation of young children's digital technology use: The parents' perspective". Cyberpsychology: Journal of Psychosocial Research on Cyberspace, 2017, 11(3), article 4. https://dx.doi.org/10.5817/CP2017-3-4

[3] S. Livingstone, G. Mascheroni, \& E. Staksrud. "European research on children's internet use: Assessing the past, anticipating the future". New Media \& Society. 2017. https://doi.org/10.1177/1461444816685930

[4] S. Youn, "Parental influence and teens' attitude toward online privacy protection". Journal of Consumer Affairs, 2018, 42, 362-388. http://dx.doi.org/10.1111/j.1745-6606.2008.00113.x

[5] V. Braun, \& V. Clarke. "Using thematic analysis in psychology". Qualitative Research in Psychology, 2006 3, 77-101. https://doi.org/10.1191/1478088706qp063oa

[6] B. Zaman, M. Nouwen, J. Vanattenhoven, E. de Ferrerre, \& J. Van Looy. "A qualitative inquiry into the contextualized parental mediation practices of young children's digital media use at home". Journal of Broadcasting \& Electronic Media, 2016, 60, 1-22. http://dx.doi.org/10.1080/08838151.2015.1127240

[7] S. Livingstone, \& E.J. Helsper. "Parental mediation of children's internet use". Journal of

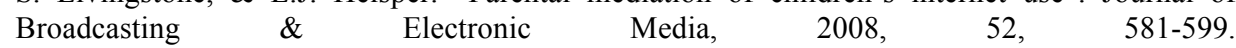
http://dx.doi.org/10.1080/08838150802437396

[8] G. S. Mesch. "Parental mediation, online activities, and cyberbullying". Cyber Psychology \& Behavior, 2009 12, 387-393. http://dx.doi.org/10.1089/cpb.2009.0068 